\title{
GMR
}

\section{Diallel and prediction (REML/BLUP) for yield components in intervarietal maize hybrids}

\author{
I.R. Carvalho ${ }^{1}$, A.J. de Pelegrin ${ }^{1}$, V.J. Szareski ${ }^{2}$, M. Ferrari ${ }^{1}$, \\ T.C. da Rosa ${ }^{1}$, T.S. Martins ${ }^{1}$, N.L. dos Santos ${ }^{1}$, M. Nardino ${ }^{3}$, \\ V.Q. de Souza ${ }^{4}$, A.C. de Oliveira ${ }^{1}$ and L.C. da Maia ${ }^{1}$ \\ ${ }^{1}$ Centro de Genômica e Fitomelhoramento, \\ Universidade Federal de Pelotas, Capão do Leão, RS, Brasil \\ ${ }^{2}$ Departamento de Fitotecnia, Universidade Federal de Pelotas, \\ Capão do Leão, RS, Brasil \\ ${ }^{3}$ Departamento de Matemática e Estatística, \\ Universidade Federal de Pelotas, Capão do Leão, RS, Brasil \\ ${ }^{4}$ Universidade Federal do Pampa, Dom Pedrito, RS, Brasil \\ Corresponding author: I.R. Carvalho \\ E-mail: carvalho.irc@gmail.com
}

Genet. Mol. Res. 16 (3): gmr16039734

Received May 24, 2017

Accepted August 4, 2017

Published August 31, 2017

DOI http://dx.doi.org/10.4238/gmr16039734

Copyright $(2017$ The Authors. This is an open-access article distributed under the terms of the Creative Commons Attribution ShareAlike (CC BY-SA) 4.0 License.

\begin{abstract}
Genetic improvement is essential to achieve increments in maize (Zea mays L.) grain yield components. It may be obtained through crosses, which enable to exploit the effects of intervarietal heterosis, allelic complementarity, as well as gene actions and effects. This study estimated the components of variance and genetic parameters (REML/BLUP) of an intervarietal diallel to select and predict the best genotypes for maize yield components. The experimental design was randomized blocks containing 60 intervarietal maize hybrids arranged in three repetitions. They were obtained through intervarietal crosses and evaluated in a diallel scheme, where 14 open-pollinated varieties were designated as parentals. Thus, 10 crosses were performed for each hybrid combination to obtain the number of seeds necessary for
\end{abstract}

Genetics and Molecular Research 16 (3): gmr16039734 
the competition test. The measured traits were: grain volume relative index, the mass of one hundred grains, and grain yield. The male parents and the additive genetic fraction were determinants for grain volume relative index. Mass of one hundred grains and grain yield were defined by the specific combining ability, and female parents revealed low narrow sense heritability. The female parent Taquarão and male parent Argentino Amarelo presented the best general combining abilities for the measured traits. The specific combining abilities were expressed for crosses AL 25 x Dente de Ouro Roxo, AL 25 x BRS Pampeano, and Taquarão x Argentino Branco. Genetic estimates and predictions were consistent and applicable to breeding programs and could be applied in future quantitative genetic studies of maize.

Key words: Plant improvement; Zea mays L.; Genetic parameters; Restricted maximum likelihood; Best linear unbiased prediction

\section{INTRODUCTION}

In the maize genetic improvement (Zea mays L.), many traits are determined by quantitative inheritance, being controlled by a large number of genes highly influenced by environmental conditions, which culminates in the low heritability of these traits in the progenies (Allard, 1971). Unquestionably, achieving higher yielding genotypes is the goal of many plant breeders. However, germplasm choice, parental combining ability, environmental effects, and selection strategies are some obstacles to obtaining high genetic potential genotypes (Falconer and Mackay, 1996).

Several maize breeding programs use open-pollinated varieties (OPVs) as a source of genetic variability and favorable alleles of target traits. Researchers report that OPVs may be economically viable, reveal phenotypic plasticity, and present wide adaptability to growing environments; however, low yield may occur (Pípolo et al., 2010). Increments in yield components may be achieved through crosses, which enable to exploit the effects of intervarietal heterosis, allelic complementarity, as well as gene actions and effects (Hallauer and Miranda Filho, 1995).

The diallel analysis provides essential parameters for selection, reveals the contribution of additive effects through the general combining ability (GCA), and also allows obtaining the specific combining ability (SCA) based on non-additive deviations from the effects of dominance and epistasis (Vencovsky, 1987). The inferences made in maize breeding are based on measurements of phenotypic traits, indicating the availability of consistent genetic information with less environmental influence essential to the breeder. It is possible to determine the parentals' additive genetic contribution to the progenies, and also to estimate parameters that quantify the trait inheritable fraction (Borges et al., 2010). Reports show that the use of mixed models allows one to obtain variance components and genetic parameters through the restricted maximum likelihood (REML). These models are flexible and may aid selection and genotype prediction through the best linear unbiased prediction (BLUP), making inferences about the genetic value, and new mean (NM) predicted for subsequent cultivation (Resende and Duarte, 2007). Therefore, the aim of this study was to estimate the components of variance and genetic parameters (REML/BLUP) of an intervarietal diallel to select and predict the best genotypes for maize yield components.

Genetics and Molecular Research 16 (3): gmr16039734 


\section{MATERIAL AND METHODS}

\section{Plant material}

Sixty intervarietal maize hybrids were obtained through intervarietal crosses and evaluated in a diallel scheme, where 14 OPVs were designated as parentals. Thus, 10 crosses were performed for each hybrid combination to obtain the number of seeds necessary for the competition test. The parentals used in diallel crosses (OPVs) and intervarietal hybrids are shown in Table 1.

Table 1. Description of parentals (OPVs) used in the maize diallel scheme and the intervarietal hybrid combinations achieved.

\begin{tabular}{|c|c|c|c|c|c|}
\hline Parentals & \multicolumn{3}{|c|}{ Open-pollinated varieties (OPV) } & \multicolumn{2}{|l|}{ Abbreviation } \\
\hline $\mathrm{G}_{1}$ & \multicolumn{3}{|c|}{ BRS 473} & \multicolumn{2}{|l|}{473} \\
\hline $\mathrm{G}_{2}$ & \multicolumn{3}{|l|}{ AL25 } & \multicolumn{2}{|l|}{ AL25 } \\
\hline $\mathrm{G}_{3}$ & \multicolumn{3}{|l|}{ AL30 } & \multicolumn{2}{|l|}{ AL30 } \\
\hline $\mathrm{G}_{4}$ & \multicolumn{3}{|c|}{ Argentino Amarelo } & \multicolumn{2}{|l|}{ ARA } \\
\hline G5 & \multicolumn{3}{|c|}{ Argentino Branco } & \multicolumn{2}{|l|}{ ARB } \\
\hline $\mathrm{G}_{6}$ & \multicolumn{3}{|c|}{ Bico de Ouro } & \multicolumn{2}{|l|}{ BIO } \\
\hline $\mathrm{G}_{7}$ & \multicolumn{3}{|l|}{ BRS Missões } & \multicolumn{2}{|l|}{ BRSM } \\
\hline $\mathrm{G}_{8}$ & \multicolumn{3}{|l|}{ Cateto Amarelo } & \multicolumn{2}{|l|}{ CAM } \\
\hline G9 & \multicolumn{3}{|l|}{ Caiano Rajado } & \multicolumn{2}{|l|}{ CR } \\
\hline $\mathrm{G}_{10}$ & \multicolumn{3}{|c|}{ Dente de Ouro Roxo } & \multicolumn{2}{|l|}{ DOR } \\
\hline $\mathrm{G}_{11}$ & \multicolumn{3}{|c|}{ BRS Pampeano } & \multicolumn{2}{|l|}{ PAM } \\
\hline $\mathrm{G}_{12}$ & \multicolumn{3}{|c|}{ Taquarão } & \multicolumn{2}{|l|}{ TAQ } \\
\hline $\begin{array}{l}\mathrm{G}_{13} \\
\mathrm{G}_{14}\end{array}$ & \multicolumn{3}{|c|}{$\begin{array}{l}\text { Branco Oito Carreiras } \\
\text { Dente de Ouro Branco }\end{array}$} & \multicolumn{2}{|l|}{$\begin{array}{l}\text { OCB } \\
\text { DOB }\end{array}$} \\
\hline \multicolumn{6}{|c|}{ Intervarietal crosses $(2014 / 2015)$} \\
\hline AL25_x_DOR & PAM_x_AL25 & CR_x_473 & AL30_x_CR & DOR_x_BIO & PAM_x_CR \\
\hline PAM_x_OCB & AL25_x_CR & BRSM_x_TAQ & CR_x_OCB & AL25_x_CAM & BRSM_x_CAM \\
\hline TAQ_x_CR & AL25_x_PAM & BRSM_x_PAM & $473 \times$ x_ARB & CAM_x_PAM & BRSM_x_OCB \\
\hline CAM_x_ARA & TAQ_x_OCB & CAM_x_OCB & DOR_x_473 & ARA_x_PAM & AL25_x_ARA \\
\hline ARA_x_ARB & ARB_x_PAM & DOR_x_OCB & AL25_x_ARB & BRSM_x_ARB & 473 x_PAM \\
\hline TAQ_x_ARB & AL25_x_473 & PAM_x_BRSM & BRSM_x_BIO & DOR_x_ARB & $473 \_\mathrm{x} \_$OCB \\
\hline DOR_x_TAQ & 473_x_ARA & DOR_x_PAM & 473 x_TAQ & ARA_x_TAQ & PAM_x_473 \\
\hline DOR_x_ARA & $473 \times$ x_CAM & AL30_x_BRSM & AL30_x_OCB & CAM_x_ARB & AL30_x_AL25 \\
\hline AL30_x_473 & AL25_x_OCB & CR_x_BRSM & DOR_x_BRSM & AL30_x_DOB & DOR_x_CR \\
\hline AL30_x_PAM & CAM_x_BIO & AL25_x_BRSM & CR_x_ARA & BIO_x_ARA & AL25_x_TAQ \\
\hline
\end{tabular}

\section{Experimental design}

The experiment was conducted at the Plant Genomics and Breeding Center of the Federal University of Pelotas. The genotypes were crossed (2014/2015) and cultivated (2015/2016) at the Palma Agricultural Center, in the city of Capão do Leão-RS, Brazil, at alatitude of $31^{\circ} 47^{\prime} 58^{\prime \prime} \mathrm{S}$ and longitude of $52^{\circ} 31^{\prime} 02^{\prime \prime} \mathrm{O}$, with an altitude of $13.2 \mathrm{~m}$. According to Köppen, the climate is classified as subtropical Cfa, and the soil is characterized as Dystrophic Yellow Red Argisol (Embrapa, 2006).

The experimental design was randomized blocks. The seeding occurred in the first half of December 2015, with a population density of 80,000 plants per hectare. The base fertilization consisted of $350 \mathrm{~kg} / \mathrm{ha}$ NPK in the formulation 10-20-20. For topdressing, $112 \mathrm{~kg} /$ ha nitrogen in the acidic form was applied at the V4 phenological stage. The control of weeds and pests were carried out preventively to reduce biotic effects in the experimental results. The experimental unit consisted of two lines of $5 \mathrm{~m}$ in length, spaced $0.50 \mathrm{~m}$. The harvest occurred in the second half of April 2016, when all genotypes presented foliar senescence.

Genetics and Molecular Research 16 (3): gmr16039734 


\section{Assessed traits}

The following agronomic traits were evaluated: Grain volume relative index (GVRI): this index was obtained by random sampling of 10 grains per experimental unit, using a digital caliper to measure grain size (mm). Subsequently, a relative index that allowed to combine information regarding grain dimensions and to infer a single tendency for the estimates was developed, being:

$$
G V R I=\square\left[\left(L^{*} W^{*} T\right) / \Sigma(L+W+T)\right]
$$

(Equation 1)

where $\mathrm{L}$ is length, $\mathrm{W}$ is the width, and $\mathrm{T}$ is the thickness of maize grains (Carvalho et al., 2016). Mass of one hundred grains (MHG): eight subsamples of one hundred grains were stratified to measure the mass through a digital scale. The results composed the trait average for the experimental unitand are reported in grams $(\mathrm{g})$.

Grain yield (GY): it was measured by harvesting all the experimental unit spikes where mass was measured. The magnitude verified was corrected for the mass of grains per plant and humidity of $13 \%$; then, the results were adjusted for the population density used, being the trait expressed in $\mathrm{kg} / \mathrm{ha}$ (Carvalho et al., 2014).

\section{Statistical analysis}

The data were subjected to the Shapiro and Wilk (1965) normality test, and deviance analysis was performed $(\mathrm{P} \leq 0.05)$ by the chi-square test $\left(\chi^{2}\right)$ to identify the traits with significance. To estimate variance components and genetic parameters (individual REML) of the intervarietal diallel, the model 87, developed by Resende (2007), was used. The statistical model $\mathrm{y}=\mathrm{Xr}+\mathrm{Zm}+\mathrm{Wf}+\mathrm{Tc}+\mathrm{e}$ was followed, where $\mathrm{y}$ is the data vector, $\mathrm{r}$ is the effect of repetitions (fixed), $m$ is the effect of intervarietal male parents, $f$ is the effect of intervarietal female parents (random), $\mathrm{c}$ is the effect of SCA between intervarietal parents; e is the residue effect (random).

The genetic variance of the male parent $\left(\sigma^{2} \mathrm{gm}\right)$, genetic variance of the female parent $\left(\sigma^{2} \mathrm{gf}\right)$, mean additive genetic variance $\left(\sigma^{2} \mathrm{a}\right)$, variance of the specific intervarietal combining ability between two parents $\left(\sigma^{2} \mathrm{sca}\right)$, residual variance $\left(\sigma^{2} \mathrm{e}\right)$, individual phenotypic variance $\left(\sigma^{2} \mathrm{p}\right)$, narrow sense heritability of the intervarietal additive effects for the male parent $\left(\hat{\mathrm{h}}^{2} \mathrm{mg}\right)$, narrow sense heritability of the intervarietal additive effects for the female parent $\left(\hat{\mathrm{h}}^{2} \mathrm{fg}\right)$, narrow sense heritability of the intervarietal average additive effects between parentals $\left(\hat{\mathrm{h}}^{2} \mathrm{a}\right)$, coefficient of determination of the SCA effects $\left(\mathrm{C}^{2} \mathrm{sca}\right)$, genotypic coefficient of variation among progenies $(\mathrm{CVg})$, coefficient of residual variation $(\mathrm{CVe})$, and the overall mean of the experiment were estimated.

Single BLUP were estimated to obtain the mean components of the general intervarietal combining ability, and to select the best intervarietal parents (male and female), to estimate the specific intervarietal combining ability, to rank the genotypes $(\mathrm{R})$ to evidence the predicted genetic effects $(G)$, predicted additive genetic value $(U+G)$, percentage of genetic gain with selection (Gain\%), and NM. The analyses were performed using the Selegen statistical software (Resende, 2007).

Genetics and Molecular Research 16 (3): gmr16039734 


\section{RESULTS AND DISCUSSION}

Deviance analysis revealed significance for GVRI, the MHG, and GY to $5 \%$ of probability by the chi-square test (Table 2). Thus, the estimates of variance components and genetic parameters present reliability and consistency for the measured traits in the 60 intervarietal maize hybrids. The GVRI gathers the dimensions of maize grains and may aid selecting genotypes of wide, long, and thick grains, being possible to increment their mass and indirectly, the genotype yield. The number of grain rows in the spike and number of grains per row influenced grain width and thickness. Otherwise, the ratio between spike and cob diameter interacts with grain length. Greater dimensions may result in increments of endosperm reserves and heavier grains (Vazquez et al., 2012).

\begin{tabular}{|c|c|c|c|}
\hline Parameters/ & GVRI (index) & MHG (g) & GY (kg/ha) \\
\hline Deviance & $7.85 * *$ & $4.74 *$ & $135.69 * *$ \\
\hline$\sigma^{2} m g$ & 1.54 & 0.39 & 5463.05 \\
\hline$\sigma^{2} f g$ & 0.52 & 1.08 & 36276.84 \\
\hline$\sigma^{2} \mathrm{a}$ & 4.14 & 2.96 & 83479.79 \\
\hline$\sigma^{2} \mathrm{sca}$ & 0.04 & 5.29 & 4833116.15 \\
\hline$\sigma^{2} \mathrm{e}$ & 6.43 & 34.98 & 1185564.92 \\
\hline$\sigma^{2} \mathrm{p}$ & 8.55 & 41.76 & 6060420.97 \\
\hline$\hat{h}^{2} m g$ & 0.72 & 0.03 & 0.00 \\
\hline$\hat{h}^{2} f g$ & 0.24 & 0.10 & 0.02 \\
\hline$\hat{h}^{2} a$ & 0.48 & 0.07 & 0.01 \\
\hline$C^{2} s c a$ & 0.00 & 0.12 & 0.79 \\
\hline$C V g(\%)$ & 6.94 & 6.90 & 31.14 \\
\hline $\mathrm{CVe}(\%)$ & 12.11 & 15.68 & 15.36 \\
\hline Overall mean & 20.94 & 37.70 & 7088.26 \\
\hline
\end{tabular}

$\sigma^{2} m g$ : genetic variance of the male parent, $\sigma^{2} f g$ : genetic variance of the female parent, $\sigma^{2}$ a: mean additive genetic variance, $\sigma^{2} s c a$ : variance of the specific combining ability between two parentals, $\sigma^{2} e$ : residual variance, $\sigma^{2} \mathrm{p}$ : individual phenotypic variance, $\hat{\mathrm{h}}^{2} m g$ : narrow sense heritability of intervarietal additive effects for the male parent, $\hat{\mathrm{h}}^{2} f g$ : narrow sense heritability of intervarietal additive effects for the female parent, $\hat{\mathrm{h}}^{2} a$ : narrow sense heritability of the mean intervarietal additive effects between parentals, $C^{2} c e c$ : coefficient of determination of the specific combining ability effects, $\mathrm{CVg}(\%)$ : coefficient of genotypic variation between progenies, $\mathrm{CVe}(\%)$ : coefficient of residual variation, Overall mean: experiment overall mean. GVRI, grain volume relative index; MHG, the mass of one hundred grains; GY, grain yield.*,**Deviance to $5 \%$ of probability by the chi-square test.

The GVRI phenotypic expression $\left(\sigma^{2} p\right)$ was determined by $48.4 \%$ of additive genetic effects $\left(\sigma^{2} a\right)$, even occurring genetic increments to the trait due to intervarietal crossings, it is noticed the absence of uniformity in the genetic contribution between parentals, where $18.5 \%$ of the phenotype $\left(\sigma^{2} \mathrm{p}\right)$ was originated from the male parent genetic fraction $\left(\sigma^{2} \mathrm{mg}\right)$, and only $6.0 \%$ was from the female parent $\left(\sigma^{2} \mathrm{fg}\right)$. The SCA contribution $\left(\sigma^{2} \mathrm{SCA}\right)$ was inferior to $1.0 \%$; thereby, the broad genetic base used for intervarietal maize breeding preconized the additive effects and favorable genes to the trait, with smaller emphasis to dominance deviations intrinsic of SCA estimates (Paini et al., 1996). For this trait, it was possible to infer that the pollen donor parent $\left(\sigma^{2} \mathrm{mg}\right.$ ) was superior, partitioning $37.2 \%$ of the total genetic effects into the additive genetic variance $\left(\sigma^{2} a\right)$. Therefore, it is implicit that dominance deviations act jointly and randomly to additive effects in intervarietal maize crosses.

Regarding the narrow sense heritability $\left(\hat{\mathrm{h}}^{2}\right)$ for GVRI, a divergence in the effects of parentals' magnitudes was observed, where high narrow sense heritability ( $\hat{\mathrm{h}}^{2} \mathrm{mg}: 0.72$ )

Genetics and Molecular Research 16 (3): gmr16039734 
was verified for intervarietal additive effects of the male parent. Otherwise, low magnitudes ( $\left.\hat{\mathrm{h}}^{2} \mathrm{fg}: 0.24\right)$ were revealed for the female parent. Regarding maize breeding, Hallauer and Miranda Filho (1995) classified the heritability as high $\left(\hat{\mathrm{h}}^{2}>70\right)$, mean or intermediate $\left(30<\hat{\mathrm{h}}^{2}\right.$ $<70)$, and low $\left(\hat{\mathrm{h}}^{2}<30\right)$. The results for these parameters may occur due to the higher additive genetic contribution of the male intervarietal parent $\left(\sigma^{2} \mathrm{mg}\right)$ on the trait phenotypic expression. Thus, a greater heritable fraction on the progeny may be achieved using the best parentals for the trait GVRI, which enable the higher additive genetic contribution in the crossing.

The mean narrow sense heritability between parentals ( $\hat{\mathrm{h}}^{2} \mathrm{a}: 0.48$ ) presented intermediate magnitude, indicating that maize breeding methods aiming to achieve elevated GVRI intervarietal hybrids become possible through the mean additive genetic effect of the parentals. In a study involving crosses of six OPVs, low narrow sense heritability ( $\left.\hat{\mathrm{h}}^{2}: 0.10\right)$ was observed for grain length, width, and thickness (Carvalho et al., 2016). The coefficient of genotypic variation (CVg: 6.94\%) verified for intervarietal hybrids evidenced variability, being $57.3 \%$ of the GVRI total variation occurring from the total genetic fraction present among genotypes.

The GVRI overall mean was 20.94 for the 60 intervarietal hybrids, corresponding to grains with $12.0 \mathrm{~mm}$ long, $10.1 \mathrm{~mm}$ wide, and $4.6 \mathrm{~mm}$ thick.

The MHG phenotypic performance $\left(\sigma^{2} p\right)$ was influenced $12.7 \%$ by the parental SCA $\left(\sigma^{2} \mathrm{SCA}\right)$, being this contribution superior to the one observed for the additive genetic fraction $\left(\sigma^{2} \mathrm{a}: 7.1 \%\right)$, male parent $\left(\sigma^{2} \mathrm{mg}: 0.9 \%\right)$ and female parent $\left(\sigma^{2} \mathrm{fg}: 2.6 \%\right)$. The additive genetic proportion $\left(\sigma^{2} a\right)$ evidenced on the progeny was $36.5 \%$ due to the female parent genetic effects $\left(\sigma^{2} \mathrm{fg}\right)$, and $13.2 \%$ from the pollen donor parent $\left(\sigma^{2} \mathrm{mg}\right)$. The MHG of the intervarietal progenies may be increased, identifying which hybrid combination is complementary for favorable alleles to the trait, being essential to choose the female parent (OPV) carefully. Reports indicate that the efficient selection of crosses in diallel, growing environment, geneaction, and effects may determine the GCA and SCA for maize grain mass (Nardino et al., 2016).

The female parent narrow sense heritability for the MHG was low ( $\left.\hat{h}^{2} f g: 0.10\right)$.However, it was the highest value for this trait. In intervarietal progenies, the narrow sense heritability ( $\hat{\mathrm{h}}^{2}$ : 0.06) was low (Carvalho et al., 2016) for endogamic lines, the broad sense heritability $\left(\mathrm{H}^{2}: 0.60\right)$ was intermediate (Soares et al., 2011). Ina study comparing 10OPVs, a high broad sense heritability ( $\left.\mathrm{H}^{2}: 0.87\right)$ for the mass of a thousand grains was obtained (Baretta et al., 2016).

The coefficient of determination magnitude of the $\mathrm{SCA}\left(\mathrm{C}^{2} \mathrm{sca}\right)$ effects indicates which strategy should be preconized to improve the trait. Elevated coefficients relate the achievement of better genotypes through heterosis, dominance, overdominance, and epistatic effects. On the other hand, low magnitudes expose the breeder to strategies that prioritize additive genetic effects, narrow sense heritability, and GCA. The results of this study $\left(\mathrm{C}^{2} \mathrm{sca}: 0.12\right)$ revealed low coefficient for the MHG. Therefore, the achievement of superior intervarietal genotypes may be grounded on additive genetic gains. There was variability (CVg: 6.90\%) for this trait; however, the genetic effects contributed only $43.2 \%$ of the total variation for the MHG.

The GY phenotypic proportion $\left(\sigma^{2} \mathrm{p}\right)$ was promoted by $79.7 \%$ of the SCA effects $\left(\sigma^{2} \mathrm{sca}\right)$ between parentals. The additive genetic fraction $\left(\sigma^{2} \mathrm{a}\right)$ was influenced by $43.5 \%$ of genetic effects from the female parent $\left(\sigma^{2} \mathrm{fg}\right)$. Otherwise, only $6.5 \%$ were due to the male parent $\left(\sigma^{2} \mathrm{mg}\right)$. The variance components indicate the existence of specific intervarietal hybrid combinations that increase GY; however, additive genetic gains are more remarkable when a superior female parent is used. A high SCA is originated from dominance deviations, epistatic effects, heterosis, and by the presence of favorable alleles for GY (Hallauer and Miranda

Genetics and Molecular Research 16 (3): gmr16039734 
Filho, 1995). Besides achieving gains by heterosis, the intervarietal breeding may generate new populations of favorable allelic frequency, the potential for line extraction and, hereafter, hybrids (Pfann et al., 2009).

The narrow sense heritability for the male parents $\left(\hat{\mathrm{h}}^{2} \mathrm{mg}\right)$, female parents $\left(\hat{\mathrm{h}}^{2} \mathrm{fg}\right)$, and mean between parentals ( $\left.\hat{\mathrm{h}}^{2} \mathrm{a}\right)$ were low for GY. According to Hallauer and Miranda Filho (1995), the narrow sense heritability for this trait is low $\left(\hat{\mathrm{h}}^{2}: 0.18\right)$. A study comparing 28 maize genotypes grown in eight environments revealed low broad sense heritability $\left(\mathrm{H}^{2}: 0.23\right)$ for GY (Nardino et al., 2016). The coefficient of determination of the SCA ( $C^{2}$ sca: 0.79) was elevated for GY, preconizing non-additive effects (dominance, overdominance, and epistasis). The genotypic coefficient of variation (CVg: $31.1 \%$ ) of GY was higher than the residual (CVe: $15.36 \%$ ) that evidenced high genetic variability among intervarietal hybrids due to the number of studied genotypes and their different genetic bases. Reports indicate that the ratio between the genotypic and residual coefficient of variation $(\mathrm{CVg} / \mathrm{CVe})$, when equal or superior to the unit, reflects the predominance of genetic effects, and the population may promote gains towards trait improvement (Vencovsky, 1987).

The estimated effects (individual BLUP) for the GCA with14 OPVs and 60 intervarietal hybrid combinations were considered (Table 3). As a criterium for inference regarding parents (maternal and paternal), the percentage of genetic gain with selection (Gain \%) equal to or higher than $10.0 \%$ was used for all evaluated traits.

The GVRI showed that the genotypes Taquarão, AL25, Cateto Amarelo, and Argentino Branco, when selected as the female parent, presented a predicted genetic gain of 22.8, 17.8, 13.2 , and $10.9 \%$, respectively. However, the selection for the best male parent indicates that the genotypes Dente de Ouro Roxo, Branco Oito Carreiras, and Argentino Amarelo provide a predicted genetic gain of 28.1, 16.4, and $12.1 \%$ for this trait.

To increase the dimensions of maize grains in intervarietal progenies, the GCA of selected parents may be exploited, comprehending which genotypes should be used as pollen donor or recipient, and still to achieve the highest additive genetic gain for the trait. The selected female parents evidenced new predicted overall mean (NM) of 21.7 and male parents of 22.6 for the GVRI. Therefore, the effective choice of the parents imposes a genetic gain when compared to the overall trait mean of 3.6 and $7.9 \%$ for the female and male parents, respectively.

Regarding MHG, it was possible to determine that genotypes AL25, Taquarão, BRS Pampeano, and AL30 obtained predicted genetic gains of 16.7, 14.0, 13.1, and 11.1\% when used as female parents. The selection of paternal parents revealed a predicted genetic gain of $18.1,16.1,14.1$, and $11.3 \%$ for the genotypes BRS Pampeano, Branco Oito Carreiras, Argentino Amarelo, and BRS 473. The grain mass gains verified in these genotypes may be because they have been previously improved, which increase the frequency of favorable alleles and the complementarity of their additive effects on the intervarietal progenies. Studies using 10OPVs define that, in average, these genotypes show a larger MHG when compared to single- and double-cross maize hybrids (Baretta et al., 2016).

OPVs and intervarietal hybrids may be economically more viable, with low production costs, phenotypic plasticity, broad adaptability, more tolerant to some diseases, and GY pondered by their level of breeding and management (Carpentieri-Pípolo et al., 2010). The selected female parents achieved a new predicted mean (NM) of $38.0 \mathrm{~g}$, and the male parents, of $38.3 \mathrm{~g}$ for the MHG. By using the best parentals, it was possible to obtain a predicted genetic gain of $1.6 \%$ for female parents and $0.8 \%$ for male parents, when compared to the trait overall mean.

Genetics and Molecular Research 16 (3): gmr16039734 
Table 3. Estimates of means for intervarietal general combining ability (GCA), and selection of intervarietalparentals (individual BLUP) for grain volume relative index (GVRI), the mass of one hundred grains (MHG), and grain yield (GY).

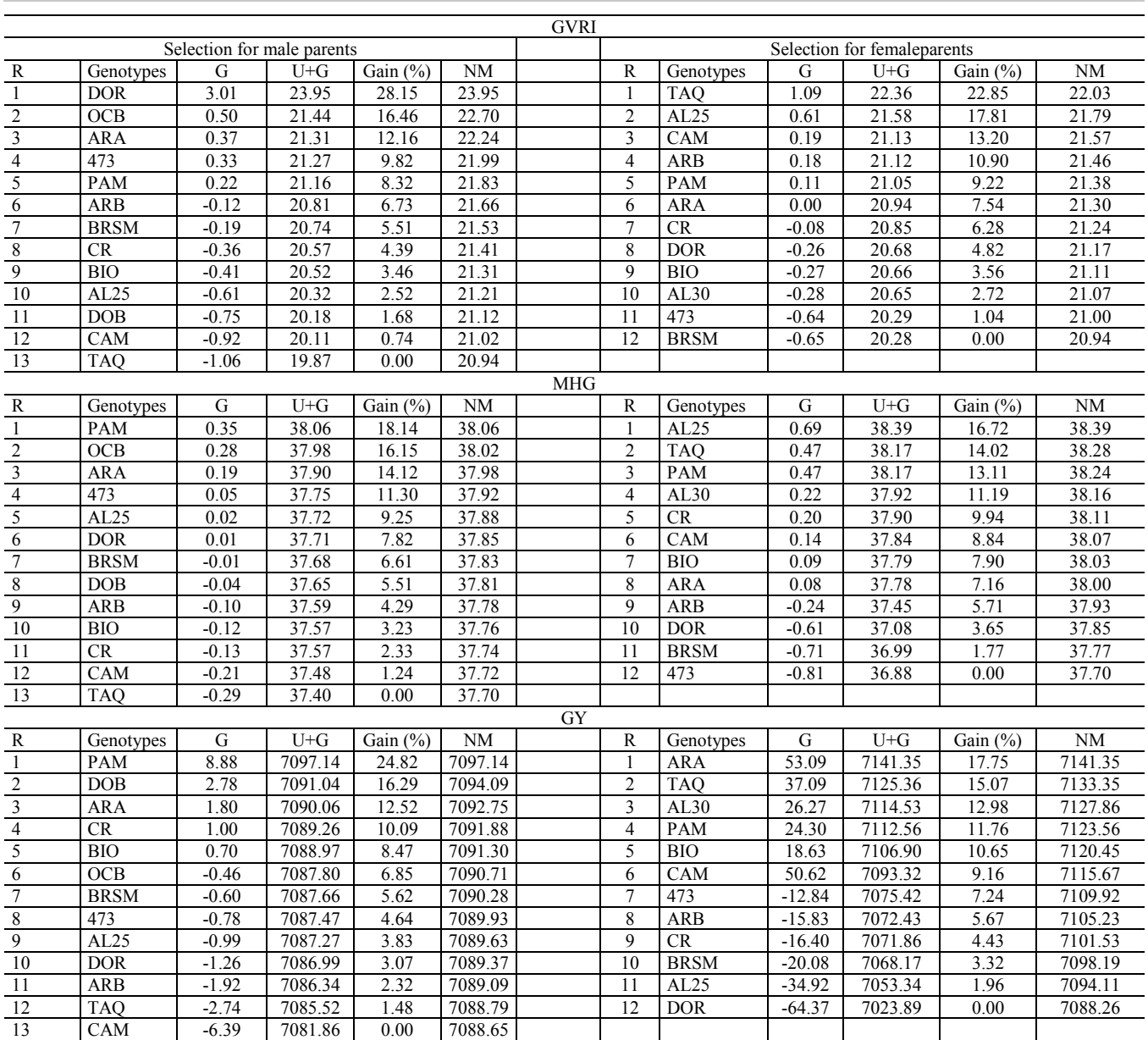

R: ranking of classification, G: predicted genetic effects, $\mathrm{U}+\mathrm{G}$ : predicted additive genetic effect, gain (\%): percentage of genetic gain with selection, NM: new mean. Parents: BRS 473 (473), AL 25 (AL25), AL 30 (AL30), Argentino Amarelo (ARA), Argentino Branco (ARB), Bico de Ouro (BIO), BRS Missões (BRSM), Cateto Amarelo (CAM), Caiano Rajado (CR), Dente de Ouro Roxo (DOR), BRS Pampeano (PAM), Taquarão (TAQ), Branco Oito Carreiras (OCB), and Dente de Ouro Banco (DOB).

GY indicates that genotypes Argentino Amarelo, Taquarão, AL30, BRS Pampeano, and Bico de Ouro showed the highest predicted genetic gains of 17.7, 15.0,12.9, 11.7, and $10.6 \%$ when used as female parents, respectively. By selecting male parents, it was possible to determine predicted genetic gains of $24.8,16.2,12.5$, and $10.0 \%$ for BRS Pampeano, Dente de Ouro Branco, Argentino Amarelo, and Caiano Rajado, respectively. The estimates suggest that even selecting the best female and male parents through the GCA, the genetic increase expressed by the trait predicted mean in the intervarietal progeny was lower than $1.0 \%$ when compared to GY overall mean. Therefore, higher probabilities of identifying superior hybrid

Genetics and Molecular Research 16 (3): gmr16039734 
combinations are evidenced through the SCA, exploiting dominance deviations, epistatic effects, and intervarietalheterosis.

The mean component estimation by BLUP for the SCA evidenced, for GVRI, that 43 intervarietal hybrids obtained a new predicted mean (NM) above the overall mean (Table 4). Otherwise, only 22 genotypes showed increases due to genetic effects $(\mathrm{G})$ positively influencing the predicted genetic value $(\mathrm{U}+\mathrm{G})$. Maize breeding lacks the genetic values for interest traits; thereby, the use of BLUP predictions allow sone to understand and select promising genotypes through information that reveals the true genetic value and minimizes estimate distortions due to environmental effects (Borges et al., 2010).

Table 4. Specific combining ability mean component estimates by BLUP for grain volume relative index (GVRI) measured in 60 intervarietal maize hybrids.

\begin{tabular}{|c|c|c|c|c|c|c|c|c|c|c|c|}
\hline $\mathrm{R}$ & Genotypes & $\mathrm{G}$ & $\mathrm{U}+\mathrm{G}$ & Gain (\%) & NM & $\mathrm{R}$ & Genotypes & $\mathrm{G}$ & $\mathrm{U}+\mathrm{G}$ & Gain (\%) & NM \\
\hline 1 & AL25_x_DOR & 0.07 & 21.01 & 0.06 & 21.01 & 31 & AL30_x_CR & -0.00 & 20.93 & 0.01 & 20.95 \\
\hline 2 & PAM_x_OCB & 0.03 & 20.97 & 0.04 & 20.99 & 32 & CR_x_OCB & -0.00 & 20.93 & 0.01 & 20.95 \\
\hline 3 & TAQ $x \_C R$ & 0.03 & 20.97 & 0.04 & 20.99 & 33 & $473 \times$ x_ARB & -0.00 & 20.93 & 0.01 & 20.95 \\
\hline 4 & CAM_x_ARA & 0.03 & 20.97 & 0.03 & 20.98 & 34 & DOR_x_473 & -0.00 & 20.93 & 0.01 & 20.95 \\
\hline 5 & ARA_x_ARB & 0.03 & 20.97 & 0.03 & 20.98 & 35 & AL25_x_ARB & -0.00 & 20.93 & 0.01 & 20.95 \\
\hline 6 & TAQ_x_ARB & 0.02 & 20.96 & 0.03 & 20.98 & 36 & BRSM_x_BIO & -0.00 & 20.93 & 0.01 & 20.95 \\
\hline 7 & DOR_x_TAQ & 0.02 & 20.96 & 0.03 & 20.98 & 37 & 473_x_TAQ & -0.00 & 20.93 & 0.01 & 20.95 \\
\hline 8 & DOR_x_ARA & 0.02 & 20.96 & 0.03 & 20.97 & 38 & AL30_x_OCB & -0.00 & 20.93 & 0.01 & 20.95 \\
\hline 9 & AL30_x_473 & 0.02 & 20.96 & 0.02 & 20.97 & 39 & DOR_x_BRSM & -0.01 & 20.93 & 0.01 & 20.95 \\
\hline 10 & AL30 X PAM & 0.02 & 20.96 & 0.02 & 20.97 & 40 & CR_x_ARA & -0.01 & 20.92 & 0.00 & 20.95 \\
\hline 11 & PAM $\times$ AL25 & 0.02 & 20.96 & 0.02 & 20.97 & 41 & DOR x BIO & $\begin{array}{l}-0.01 \\
\end{array}$ & 20.92 & 0.00 & 20.95 \\
\hline 12 & AL25_x_CR & 0.02 & 20.96 & 0.02 & 20.97 & 42 & AL25_x_CAM & -0.01 & 20.92 & 0.00 & 20.95 \\
\hline 13 & AL25_x_PAM & 0.01 & 20.95 & 0.02 & 20.97 & 43 & CAM_x_PAM & -0.01 & 20.92 & 0.00 & 20.95 \\
\hline 14 & TAQ_x_OCB & 0.01 & 20.95 & 0.02 & 20.97 & 44 & ARA_x_PAM & -0.01 & 20.92 & 0.00 & 20.94 \\
\hline 15 & ARB_x_PAM & 0.01 & 20.95 & 0.02 & 20.96 & 45 & BRSM_x_ARB & -0.01 & 20.92 & 0.00 & 20.94 \\
\hline 16 & AL25_x_473 & 0.01 & 20.95 & 0.02 & 20.96 & 46 & DOR_x_ARB & -0.01 & 20.92 & 0.00 & 20.94 \\
\hline 17 & 473_x_ARA & 0.01 & 20.95 & 0.02 & 20.96 & 47 & ARA_x_TAQ & -0.01 & 20.92 & 0.00 & 20.94 \\
\hline 18 & 473_x_CAM & 0.01 & 20.95 & 0.02 & 20.96 & 48 & CAM_x_ARB & -0.01 & 20.92 & 0.00 & 20.94 \\
\hline 19 & AL25_x_OCB & 0.01 & 20.95 & 0.02 & 20.96 & 49 & AL30_x_DOB & -0.01 & 20.92 & 0.00 & 20.94 \\
\hline 20 & CAM_x_BIO & 0.01 & 20.95 & 0.01 & 20.96 & 50 & BIO_x_ARA & -0.02 & 20.91 & 0.00 & 20.94 \\
\hline 21 & CR_x_473 & 0.01 & 20.95 & 0.01 & 20.96 & 51 & PAM_x_CR & -0.02 & 20.91 & 0.00 & 20.94 \\
\hline 22 & BRSM_x_TAQ & 0.01 & 20.95 & 0.01 & 20.96 & 52 & BRSM_x_CAM & -0.02 & 20.91 & 0.00 & 20.94 \\
\hline 23 & BRSM $x$ PAM & 0.00 & 20.94 & 0.01 & 20.96 & 53 & BRSM x OCB & -0.02 & 20.91 & 0.00 & 20.94 \\
\hline 24 & CAM_x_OCB & 0.00 & 20.94 & 0.01 & 20.96 & 54 & AL25_x_ARA & -0.02 & 20.91 & 0.00 & 20.94 \\
\hline 25 & DOR_x_OCB & 0.00 & 20.94 & 0.01 & 20.96 & 55 & 473_x_PAM & -0.02 & 20.91 & 0.00 & 20.94 \\
\hline 26 & PAM_x_BRSM & 0.00 & 20.94 & 0.01 & 20.96 & 56 & 473 x_OCB & -0.03 & 20.91 & 0.00 & 20.94 \\
\hline 27 & DOR_x_PAM & 0.00 & 20.94 & 0.01 & 20.96 & 57 & PAM_x_473 & -0.03 & 20.90 & 0.00 & 20.94 \\
\hline 28 & AL30_x_BRSM & 0.00 & 20.94 & 0.01 & 20.96 & 58 & AL30_x_AL25 & -0.03 & 20.90 & 0.00 & 20.94 \\
\hline 29 & CR_x_BRSM & 0.00 & 20.94 & 0.01 & 20.95 & 59 & DOR_x_CR & -0.04 & 20.89 & 0.00 & 20.94 \\
\hline 30 & AL25_x_BRSM & -0.00 & 20.93 & 0.06 & 20.95 & 60 & AL25_x_TAQ & -0.04 & 20.89 & 0.00 & 20.94 \\
\hline
\end{tabular}

R: ranking of classification, G: predicted genetic effects, $\mathrm{U}+\mathrm{G}$ : predicted additive genetic effect, gain (\%): percentage of genetic gain with selection, NM: new mean.

Parents: BRS 473 (473), AL 25 (AL25), AL 30 (AL30), Argentino Amarelo (ARA), Argentino Branco (ARB), Bico de Ouro (BIO), BRS Missões (BRSM), Cateto Amarelo (CAM), Caiano Rajado (CR), Dente de Ouro Roxo (DOR), BRS Pampeano (PAM), Taquarão (TAQ), Branco Oito Carreiras (OCB), and Dente de Ouro Banco (DOB).

The predictions for GVRI determine that higher SCA were obtained by the crossing between the female parent AL 25, and male parent Dente de Ouro Roxo (AL25_x_DOR), revealing, for the predicted additive genetic value $(\mathrm{U}+\mathrm{G})$ and $\mathrm{NM}(21.01)$, superiority to the other genotypes. The achievement of intervarietal genotypes with greater grain dimensions also may occur through the crosses BRS Pampeano and Branco Oito Carreiras (PAM_x_

Genetics and Molecular Research 16 (3): gmr16039734 
OCB), Taquarão and Caiano Rajado (TAQ_x_CR).However, these crosses presented smaller additive genetic gain in the progeny.

Regarding MHG, 57 intervarietal hybrids revealed that the new predicted mean (NM) was higher than the trait overall mean. Besides, increments due to predicted genetic effects $(G)$ and additive genetic effects $(U+G)$ were evidenced for 26 intervarietal hybrids (Table 5). The best SCA estimates were expressed for the female parent AL25, and male parent BRS Pampeano, which achieved genetic gain with a selection of $8.8 \%$, and the NM of 43.72 was similar to the predicted additive genetic value $(\mathrm{U}+\mathrm{G})$. The NM predicted by BLUP will present proximity to the trait magnitude in the new harvest. However, whether the estimate of predicted additive genetic value $(\mathrm{U}+\mathrm{G})$ is close to the NM, there is a high probability of this prediction to be consistent (Borges et al., 2010).

Table 5. Specific combining ability mean component estimates by BLUP for the mass of one hundred grains (MHG) measured in 60 intervarietal maize hybrids.

\begin{tabular}{|c|c|c|c|c|c|c|c|c|c|c|c|}
\hline $\mathrm{R}$ & Genotypes & $\mathrm{G}$ & $\mathrm{U}+\mathrm{G}$ & Gain $(\%)$ & NM & $\mathrm{R}$ & Genotypes & $\mathrm{G}$ & $\mathrm{U}+\mathrm{G}$ & Gain $(\%)$ & NM \\
\hline 1 & AL25 x PAM & 6.02 & 43.72 & 8.82 & 43.72 & 31 & DOR_x_BRSM & -0.24 & 37.46 & 1.18 & 38.51 \\
\hline 2 & AL30 x 473 & 2.18 & 39.89 & 6.01 & 41.80 & 32 & DOR x BIO & -0.27 & 37.43 & 1.14 & 38.48 \\
\hline 3 & BRSM_x_OCB & 2.14 & 39.85 & 5.05 & 41.15 & 33 & BRSM_x_ARB & -0.30 & 37.40 & 1.09 & 38.44 \\
\hline 4 & PAM_x_OCB & 2.09 & 39.79 & 4.56 & 40.81 & 34 & 473 x_ARB & -0.34 & 37.36 & 1.04 & 38.41 \\
\hline 5 & CAM_x_ARA & 1.72 & 39.42 & 4.15 & 40.53 & 35 & CR_x_ARA & -0.34 & 37.36 & 1.00 & 38.38 \\
\hline 6 & TAQ_x_OCB & 1.31 & 39.01 & 3.78 & 40.28 & 36 & AL25 $x \quad$ ARB & -0.37 & 37.33 & 0.95 & 38.35 \\
\hline 7 & AL30_x_PAM & 1.30 & 39.00 & 3.51 & 40.10 & 37 & CAM_x_PAM & -0.42 & 37.28 & 0.91 & 38.32 \\
\hline 8 & PAM_x_AL25 & 1.27 & 38.97 & 3.30 & 39.96 & 38 & CAM $\mathrm{x}$ BIO & -0.44 & 37.27 & 0.87 & 38.30 \\
\hline 9 & ARA_x_ARB & 1.07 & 38.77 & 3.11 & 39.83 & 39 & AL25_x_CAM & -0.47 & 37.23 & 0.83 & 38.27 \\
\hline 10 & DOR_x_PAM & 0.97 & 38.67 & 2.94 & 39.71 & 40 & DOR_x_473 & -0.52 & 37.18 & 0.79 & 38.24 \\
\hline 11 & DOR x ARA & 0.58 & 38.28 & 2.75 & 39.58 & 41 & BRSM x PAM & -0.53 & 37.18 & 0.75 & 38.22 \\
\hline 12 & TAQ_x_CR & 0.58 & 38.28 & 2.59 & 39.47 & 42 & AL25_x_BRSM & -0.54 & 37.17 & 0.72 & 38.19 \\
\hline 13 & CR_x_OCB & 0.53 & 38.23 & 2.45 & 39.38 & 43 & AL30_x_DOB & -0.57 & 37.14 & 0.68 & 38.17 \\
\hline 14 & BIO_x_ARA & 0.45 & 38.15 & 2.32 & 39.29 & 44 & AL30_x_OCB & -0.57 & 37.13 & 0.65 & 38.14 \\
\hline 15 & PAM_x_CR & 0.45 & 38.15 & 2.21 & 39.21 & 45 & CAM x ARB & -0.59 & 37.11 & 0.61 & 38.12 \\
\hline 16 & TAQ $\times$ ARB & 0.42 & 38.12 & 2.11 & 39.14 & 46 & AL30 x CR & -0.64 & 37.06 & 0.58 & 38.10 \\
\hline 17 & CAM_x_OCB & 0.42 & 38.12 & 2.02 & 39.08 & 47 & AL25_x_CR & -0.70 & 37.00 & 0.54 & 38.07 \\
\hline 18 & CR_x_BRSM & 0.42 & 38.12 & 1.95 & 39.03 & 48 & DOR_x_OCB & -0.81 & 36.89 & 0.51 & 38.05 \\
\hline 19 & $\mathrm{CR} \times 473$ & 0.41 & 38.11 & 1.87 & 38.98 & 49 & BRSM $\times$ BIO & -0.97 & 36.73 & 0.47 & 38.02 \\
\hline 20 & AL30 $x$ BRSM & 0.39 & 38.09 & 1.81 & 38.94 & 50 & AL30 x AL25 & -0.99 & 36.71 & 0.43 & 38.00 \\
\hline 21 & ARA x PAM & 0.36 & 38.06 & 1.75 & 38.90 & 51 & ARA $x$ TAQ & -1.03 & 36.67 & 0.39 & 37.97 \\
\hline 22 & AL25_x_OCB & 0.29 & 38.00 & 1.69 & 38.85 & 52 & ARB_x_PAM & -1.20 & 36.50 & 0.35 & 37.94 \\
\hline 23 & AL25_x_ARA & 0.22 & 37.92 & 1.63 & 38.81 & 53 & AL25_x_TAQ & -1.22 & 36.48 & 0.31 & 37.91 \\
\hline 24 & AL25_x_DOR & 0.17 & 37.87 & 1.57 & 38.77 & 54 & PAM_x_473 & -1.30 & 36.40 & 0.27 & 37.89 \\
\hline 25 & DOR_x_TAQ & 0.06 & 37.76 & 1.51 & 38.73 & 55 & DOR_x_ARB & -1.33 & 36.37 & 0.23 & 37.86 \\
\hline 26 & $473 \times$ ARA & 0.03 & 37.73 & 1.46 & 38.70 & 56 & DOR x CR & -1.44 & 36.27 & 0.19 & 37.83 \\
\hline 27 & AL25_x_473 & -0.01 & 37.69 & 1.40 & 38.66 & 57 & $473 \times$ OCB & -1.66 & 36.05 & 0.14 & 37.80 \\
\hline 28 & $473 \times$ x_TAQ & -0.08 & 37.62 & 1.35 & 38.62 & 58 & BRSM_x_TAQ & -1.66 & 36.05 & 0.10 & 37.77 \\
\hline 29 & $473 \times$ x_CAM & -0.21 & 37.49 & 1.29 & 38.58 & 59 & 473 x_PAM & -1.71 & 36.00 & 0.05 & 37.74 \\
\hline 30 & PAM_x_BRSM & -0.22 & 37.48 & 1.24 & 38.55 & 60 & BRSM $\times$ CAM & -2.16 & 35.54 & 0.00 & 37.70 \\
\hline
\end{tabular}

R: ranking of classification, $\mathrm{G}$ : predicted genetic effects, $\mathrm{U}+\mathrm{G}$ : predicted additive genetic effect, gain (\%): percentageof genetic gain with selection, NM:new mean.Parentals: BRS 473 (473), AL 25 (AL25), AL 30 (AL30), Argentino Amarelo (ARA), Argentino Branco (ARB), Bico de Ouro (BIO), BRS Missões (BRSM), Cateto Amarelo (CAM), Caiano Rajado (CR), Dente de Ouro Roxo (DOR), BRS Pampeano (PAM), Taquarão (TAQ), Branco Oito Carreiras (OCB), andDente de Ouro Banco (DOB).

The increment in grain mass on intervarietal progenies may also be achieved with crosses between AL30 and BRS 473 (AL30_x_473), BRS Missões and Branco Oito Carreiras (BRSM_x_OCB), BRS Pampeano and Branco Oito Carreiras (PAM_x_OCB), which reveal genetic gains of $6.0,5.0$, and $4.5 \%$, respectively. Higher additive genetic effects were verified for the MHG when an OPV with a certain degree of breeding for agronomic traits of interest was used as a female parent. In the ranking of better genotypes for SCA, superior results were

Genetics and Molecular Research 16 (3): gmr16039734 
achieved when the crossing was performed between two OPVs previously breed, being them complementary for favorable alleles controlling the mass of grains.

Regarding GY, 59 intervarietal crosses presented NM superior to the trait overall mean (Table 6). However, only 27 genotypes were benefited by these positive genetic effects (G) of the crossing. The SCA revealed higher predicted additive genetic effect $(\mathrm{U}+\mathrm{G})$ for the crossing Taquarão and Argentino Branco (TAQ_x_ARB), with a new predicted mean (NM) (12631.1 $\mathrm{kg} / \mathrm{ha}$ ) $78.1 \%$ superior to the trait overall mean. Some crosses presented productive potential. However, smaller genetic effects were verified through the hybrid combinations Cateto Amarelo and BRS Pampeano (CAM_x_PAM), AL25 and Branco Oito Carreiras (AL25_x OCB), Argentino Amarelo and Taquarão (ARA_x_TAQ), where all these combinations evidenced genetic gains with selection superior to $4.0 \%$, compared to the other genotypes.

Table 6. Specific combining ability mean component estimates by BLUP for grain yield (GY) measured in 60 intervarietal maize hybrids.

\begin{tabular}{|c|c|c|c|c|c|c|c|c|c|c|c|}
\hline $\mathrm{R}$ & Genotypes & $\mathrm{G}$ & $\mathrm{U}+\mathrm{G}$ & Gain (\%) & NM & $\mathrm{R}$ & Genotypes & G & $\mathrm{U}+\mathrm{G}$ & Gain (\%) & NM \\
\hline 1 & TAQ $x \_$ARB & 5542.8 & 12631.1 & 4.90 & 12631.1 & 31 & AL30 x BRSM & -214.1 & 6874.1 & 1.30 & 8555.7 \\
\hline 2 & CAM_x_PAM & 5088.9 & 12177.2 & 4.70 & 12404.2 & 32 & AL25_x_ARA & -409.0 & 6679.1 & 1.25 & 8497.1 \\
\hline 3 & AL25 $x$ OCB & 4004.3 & 11092.5 & 4.32 & 11966.9 & 33 & TAQ $x$ OCB & -410.6 & 6677.6 & 1.20 & 8441.9 \\
\hline 4 & ARA $x$ TAQ & 3949.0 & 11037.3 & 4.11 & 11734.5 & 34 & PAM x CR & -500.5 & 6587.6 & 1.15 & 8387.4 \\
\hline 5 & PAM $\times 473$ & 3634.5 & 10722.8 & 3.93 & 11532.2 & 35 & DOR x PAM & -512.3 & 6575.8 & 1.10 & 8335.6 \\
\hline 6 & ARA X PAM & 3098.5 & 10186.8 & 3.73 & 11307.9 & 36 & AL25 x TAQ & -538.7 & 6549.5 & 1.06 & 8286.0 \\
\hline 7 & DOR_x_BIO & 2768.6 & 9856.9 & 3.55 & 11100.7 & 37 & CAM_x_ARB & -571.6 & 6516.5 & 1.02 & 8238.2 \\
\hline 8 & BIO_x_ARA & 2479.0 & 9567.2 & 3.38 & 10909.0 & 38 & CR_x_BRSM & -687.9 & 6400.2 & 0.97 & 8189.8 \\
\hline 9 & AL30_x_DOB & 2454.8 & 9543.1 & 3.25 & 10757.2 & 39 & AL25_x_BRSM & -708.5 & 6379.7 & 0.93 & 8143.4 \\
\hline 10 & AL30 X PAM & 2331.3 & 9419.6 & 3.13 & 10623.4 & 40 & AL25 $x \quad$ ARB & -827.9 & 6260.3 & 0.89 & 8096.3 \\
\hline 11 & 473_x_ARA & 2250.6 & 9338.9 & 3.02 & 10506.7 & 41 & CAM_x_BIO & -851.6 & 6236.6 & 0.85 & 8051.0 \\
\hline 12 & BRSM_x_PAM & 1312.6 & 8400.9 & 2.87 & 10331.2 & 42 & $473 \times$ ARB & -883.6 & 6204.6 & 0.81 & 8007.0 \\
\hline 13 & PAM_x_BRSM & 1248.3 & 8336.6 & 2.73 & 10177.8 & 43 & CAM_x_ARA & -1056.8 & 6031.4 & 0.77 & 7961.1 \\
\hline 14 & AL25_x_PAM & 1245.0 & 8333.3 & 2.62 & 10046.0 & 44 & AL25 x_DOR & -1120.8 & 5967.4 & 0.73 & 7915.8 \\
\hline 15 & AL30_x_CR & 991.7 & 8079.9 & 2.50 & 9914.9 & 45 & DOR_x_ARA & -1160.3 & 5927.9 & 0.69 & 7871.6 \\
\hline 16 & BRSM_x_ARB & 715.9 & 7804.1 & 2.38 & 9783.0 & 46 & BRSM_x_BIO & -1293.5 & 5794.7 & 0.65 & 7826.4 \\
\hline 17 & $473 \times \mathrm{TAQ}$ & 593.3 & 7681.6 & 2.27 & 9659.4 & 47 & $473 \times$ OCB & -1306.8 & 5781.4 & 0.61 & 7782.9 \\
\hline 18 & AL30_x_AL25 & 519.4 & 7607.7 & 2.17 & 9545.4 & 48 & BRSM_x_TAQ & -1388.6 & 5699.5 & 0.58 & 7739.5 \\
\hline 19 & DOR_x_CR & 452.5 & 7540.7 & 2.08 & 9439.9 & 49 & PAM_x_AL25 & -1396.0 & 5692.1 & 0.54 & 7697.7 \\
\hline 20 & CR_x_473 & 445.9 & 7534.2 & 2.00 & 9344.6 & 50 & CR_x_OCB & -1427.6 & 5660.6 & 0.50 & 7657.0 \\
\hline 21 & PAM_x_OCB & 246.4 & 7334.6 & 1.91 & 9248.9 & 51 & CR_x_ARA & -1514.1 & 5574.1 & 0.47 & 7616.2 \\
\hline 22 & DOR $\times$ OCB & 231.5 & 7319.7 & 1.83 & 9161.2 & 52 & CAM $\times$ OCB & -1935.4 & 5152.8 & 0.43 & 7568.8 \\
\hline 23 & DOR x 473 & 177.6 & 7265.9 & 1.76 & 9078.8 & 53 & ARB x PAM & -2106.2 & 4982.0 & 0.38 & 7520.0 \\
\hline 24 & AL25_x_CR & 139.4 & 7227.6 & 1.69 & 9001.7 & 54 & BRSM_x_CAM & -2114.7 & 4973.5 & 0.34 & 7472.8 \\
\hline 25 & BRSM $\times$ OCB & 96.3 & 7184.5 & 1.63 & 8929.0 & 55 & AL25 x 473 & -2268.7 & 4819.5 & 0.30 & 7424.6 \\
\hline 26 & AL30_x_OCB & 95.9 & 7184.2 & 1.57 & 8861.9 & 56 & 473 x_PAM & -2302.9 & 4785.3 & 0.26 & 7377.4 \\
\hline 27 & ARA $x$ ARB & 15.3 & 7103.5 & 1.51 & 8796.8 & 57 & AL30 x 473 & -2684.0 & 4404.2 & 0.21 & 7325.3 \\
\hline 28 & $473 \times$ x_CAM & $\begin{array}{l}-58.8 \\
\end{array}$ & 7029.4 & 1.46 & 8733.6 & 58 & AL25_x_CAM & -3474.4 & 3613.7 & 0.15 & 7261.3 \\
\hline 29 & DOR_x_BRSM & -167.6 & 6920.6 & 1.40 & 8671.1 & 59 & DOR_x_ARB & -5003.5 & 2084.7 & 0.08 & 7173.5 \\
\hline 30 & TAQ $\times C R$ & -197.6 & 6890.6 & 1.35 & 8611.8 & 60 & DOR $\times$ TAQ & -5034.3 & 2053.8 & 0.00 & 7088.2 \\
\hline
\end{tabular}

$\mathrm{R}$ : ranking of classification, G: predicted genetic effects, $\mathrm{U}+\mathrm{G}$ : predicted additive genetic effect, gain (\%): percentage of genetic gain with selection, NM: new mean. Parentals BRS 473 (473), AL 25 (AL25), AL 30 (AL30), Argentino Amarelo (ARA), Argentino Branco (ARB), Bico de Ouro (BIO), BRS Missões (BRSM), Cateto Amarelo (CAM), Caiano Rajado (CR), Dente de Ouro Roxo (DOR), BRS Pampeano (PAM), Taquarão (TAQ), Branco Oito Carreiras (OCB), and Dente de Ouro Banco (DOB).

With the results presented in this study, it was possible to comprehend the additive genetic proportions and parameters essential for maize breeding, and also to determine which approaches regarding combining ability may be carried out to achieve intervarietal hybrids of superior yield components. The exposed inferences can be used in maize intervarietal breeding programs and quantitative genetic studies that use mixed models for genotype prediction.

Genetics and Molecular Research 16 (3): gmr16039734 


\section{CONCLUSIONS}

The male parents and the additive genetic fraction are determinants for GVRI, and the narrow sense heritability is intermediate for this trait. MHG and GY are defined by the SCA, and female parents reveal low narrow sense heritability. The female parent Taquarão and male parent Argentino Amarelo present the best GCA for the measured traits. The SCA are expressed for crosses AL 25 x Dente de Ouro Roxo, AL 25 x BRS Pampeano, and Taquarão x Argentino Branco. Genetic estimates and predictions are consistent and applicable to breeding programs and future quantitative genetic studies of maize.

\section{Conflicts of interest}

The authors declare no conflict of interest.

\section{ACKNOWLEDGMENTS}

The authors thank Conselho Nacional de Desenvolvimento Científico e Tecnológico (CNPq), and Coordenação de Aperfeiçoamento de Pessoal de Nível Superior (CAPES) for project financing and the granting of the first author's doctoral fellowship.

\section{REFERENCES}

Allard RW (1971). Principles of plant breeding. Edgard Blücher, São Paulo.

Baretta D, Nardino M, Carvalho IR, De Oliveira AC, et al. (2016). Performance of maize genotypes of Rio Grande do Sul using mixed models. Cientifica (Jaboticabal) 44: 403-411. https://doi.org/10.15361/1984-5529.2016v44n3p403-411

Borges V, Ferreira PV, Soares L, Santos GM, et al. (2010). Sweet potato clone selection by REML/BLUP procedure. Acta Sci. Agron. 32: 643-649.

Pípolo CV, Souza A, Silva DA, Barreto TP, et al. (2010). Evaluation of maize landrace cultivars under a low tech-system. Acta Sci. Agron. 32: 229-233.

Carvalho IR, De Souza VQ, Follmann DN, Nardino M, et al. (2014). Performance of agriculture environment in hybrid corn irrigated and non-irrigated. Enciclopédia Biosfera 10: 1144-1153.

Carvalho IR, Nardino M, Pelegrin AJ, Hoffmann JF, et al. (2016). Estimate of genetic parameters in bioactive and micronutrients compounds of maize. Afr. J. Agric. Res. 11: 3123-3133. https://doi.org/10.5897/AJAR2016.11329

Embrapa (2006). Centro Nacional de Pesquisa de Solos. Sistema Brasileiro de Classificação de Solos. Rio de Janeiro.

Falconer DS and Mackay TFC (1996). Introduction to Quantitative Genetics. 4th ed. Longmans Green, Harlow.

Hallauer AR and Miranda Filho JB (1995). Quantitative genetics in maize breeding. 2nd ed. Iowa State University Press. Ames, Iowa.

Nardino M, Souza VQ, Baretta D, Konflanz VA, et al. (2016). Partial diallel analysis among maize lines for characteristics related to the tassel and the productivity. Afr. J. Agric. Res. 11: 974-982. https://doi.org/10.5897/AJAR2014.10314

Paini JN, Cruz CD, Delboni JS, Scapim CA, et al. (1996). Capacidade combinatória e heterose em cruzamentos intervarietais de milho avaliados sob as condições climáticas da região sul do Brasil. Ceres 43: 247.

Pfann AZ, Faria MV, Andrade AA, Nascimento IR, et al. (2009). Combining ability in corn single-cross hybrids by circulant diallel. Cienc. Rural 39: 635-641. https://doi.org/10.1590/S0103-84782009000300002

Resende MDV (2007). Software Selegem - REML/BLUP: Sistema estatístico e seleção genética computadorizada via modelos lineares mistos. Embrapa Florestas, Colombo.

Resende MDV and Duarte JB (2007). Precision and quality control in variety trials. Pesqui. Agropecu. Trop. 37: 182-194. Shapiro SS and Wilk MB (1965). An analysis of variance test for normality (complete samples). Biometrics 52: 3-4.

Soares MO, Miranda GV, Guimarães LJM, Marriel IE, et al. (2011). Genetic parameters of a maize population in contrasting nitrogen levels. Cienc. Agron. 42: 168-174. https://doi.org/10.1590/S1806-66902011000100021

Vazquez GH, Arf O, Sargi BA, Pessoa ACO, et al. (2012). Corn seed size and shape influence on plant growth and grain yield. Biosci. J. 28: 16-24.

Vencovsky R (1987). Herança quantitativa. In: Melhoramento e produção do milho (Paterniani E and Viégas GP, eds.). Fundação Cargill, Campinas.

Genetics and Molecular Research 16 (3): gmr16039734 